\title{
Streamlining Sustainability: A Principal Component Reduction for Regionally Based African-Centric Indicators
}

\author{
*Jay L Newberry and Zizwe Grandison \\ Department of Geography, Binghamton University, USA \\ Submission: February 15, 2017; Published: February 28, 2017 \\ *Corresponding author: Jay L Newberry, Department of Geography, Binghamton University, Suny, Newyork USA, \\ Email: jnewber@binghamton.edu
}

\begin{abstract}
Ecological indicators were created to measure human consumption of Earth's finite resources. Since 1992, hundreds of indicators have been created at the global scale. These indicators reveal that, while there might be similarities between regions of the world, each region has its own distinctive characteristics. This article concentrates on the forty odd created for the regions of Africa. The statistical outliers from twenty plus ecological indicators were subjected to a Principal Component Analysis to reduce and create composite indicators that would better reflect the regional variability. The data reduction - or streamlining - resulted in the creation of three indicators per region (fifteen in all) that accounted for, on average, 77.6 percent of the variance in the ecological data. Out of the fifteen variables extracted, four from the original stock of indicators made it through the reduction process indicating that those particular indicators measured exactly what they were supposed to measure.
\end{abstract}

Keywords: Principal Component Analysis; Ecological Indicators; Africa; African Environment

Abbreviations: CNC: Critical National Capital; LE: Life Expectancy; ECA: Economic Commission of Africa; MDG: Millennium Development Goals; EF: Ecological Footprint; MOSOP: Movement for the Survival of the Ogoni People; EPI: Environment Performance Index; NEPAD: New Partnership for African Development; EWB: Experienced Well being; NGO: Non governmental Organization; EWI: Ecological Well being; NOAA: National Ocean and Atmospheric Adminstration; FA: Factor Analysis; PCA: Principal Component Analysis; FEWS: Famine Early Warning System; SDRA: Sustainable Development Report on Africa; GBM: Green Belt Movement; SGAP: Sustainable Gap; GDP: Gross Domestic Product; SSI: Sustainable Society Index; GHG: Greenhouse House Gas; UN: United Nations; GPI: Genuine Progress Indicator; UNCED: U.N. Conference on Environment and Develop; HDI: Human Development Index; UNCSD: UN Committee on Sustainable Development; HPI: Happy Planet Index; UNEP: UN Environment Program; HWI: Human Well being Index;USAID: United States Agency for Intl. Development; ISEW: Index of Sustainable Economic Welfare; KMO: Kaiser Meyer Oklin; USGS: US Geological Survey; WRI: World Risk Index; WSSD: World Summit on Sustainable Development.

\section{Introduction}

Over the course of millions of years, human kind has evolved from simplistic organisms growing as part of the environment to sophisticated organisms dominating the environment. This evolution resulted in humans becoming self appointed caretakers of Earth as the dominant sentient species. In within a relatively short time span geologically speaking we discovered how to harness the Earth's natural resources to improve our quality of life. Unfortunately, when one considers the path human population growth has taken, it becomes obvious that the growth facilitated a greater demand on the planet's finite resources to maintain the progressive comfort that enhances our quality of life. The spreading of human habitats all over the Earth came with a "conquer nature" mentality that owed itself to new technologies and new materials this maintenance of comfort, unfortunately, came at the expense of the natural environment [1]. Thus, the preeminent question remains - as it has for the past 40 years - how long can we continue our destructively unsustainable ways.

The expanding conceptualization of sustainability is only a recent phenomenon, but the underlying notion has been around for well over two centuries. Early re collections begin with the alarms set off by Malthus's An Essay on the Principle of Population from 1798 and John Stuart Mill's Principles of Political Economy with some of their Applications to Social Philosophy from 1848 [2]. In 1972, however, it was the book Limits to Growth that garnered worldwide attention as the authors used computer modeling to predict the demise of our ever increasing standard of living within 50 to100 years [3]. 
Thus - barring behavioral intervention on a global scale - a weakened version of the Dark Ages would return between 2022 to 2072 as we fall back on the notion of survival of the fittest. Many believe it was the lead author - Donella H. Meadows who first detailed the concept of sustainability and urged that a changing of paradigms or worldviews would be the only way to bring about a more sustainable society [3]. The very same year, out of happenstance, The United Nations (U.N.) called together The Human Environment Summit in Stockholm which involved the major industrialized countries. The general assembly would create the United Nations Environment Program (UNEP) who would, in turn, establish the Brandt Commission which was made up of politicians and scientists. The Brundtland Commission (or UN World Commission on Environment and Development) was formed in 1983 and was named after the Norwegian Prime Minister who was the chair. The mandate of the commission was to determine how humans could define and achieve sustainable development. Critics considered this task to be unattainable, but in 1987, the meaning behind the term 'sustainable development' was officially adopted from the Brundt land Commission's report [4].

In the following decade, the U.N. Conference on Environment and Development (UNCED) also known as the Earth Summit was held in Rio de Janeiro. Here, a non binding, voluntary action plan called Agenda 21 was formulated. All 172 countries in attendance approved an action plan to become more sustainable for the sake of future generations. Subsequently, there have been numerous other conferences concerning various aspects of sustainability to include the Millennium conference in New York City. The outcome of this gathering was the Millennium Development Goals (MDG). Out of the eight goals identified to be achieved by 2015 , Goal 7 was to ensure environmental sustainability. What transpired from the various conferences was the creation of numerous measuring tools called ecological indicators. The purpose of the quantitative indicators is to measure the health of the environment; and, as a whole, the indicators are held as the key to establishing a more comprehensive knowledge base on Earth's ecology. The use of indicators is nothing new, but ecological indicators tend to be more inclusive than other performance measures and focus more on showing trends concerning critical environmental and social problems [3].

\section{Objective}

The objective of this paper is to develop composite ecological indicators that can accurately measure the environmental health of some of Africa's more diverse sub regions. As the term 'composite' implies, we are looking to develop new African specific indicators based on pre existing indicators by way of a data reduction technique. Most African sub regions have particular environmental deficiencies - indicators will be developed that pertain specifically to the region based deficiencies. Hundreds of indicators have already been created which might make this research redundant, but the long range goal is to develop African specific indicators that can accurately monitor African sustainability. This text will first explore the concept of sustainable development and environmental indicators. Then, we will explore the focus on Africa. Next, the methodology will be elaborated on followed by the results and a conclusion.

\section{Sustainability and Sustainable Development}

The concept of sustainability emerged in response to the increased understanding that contemporary development practices were leading to crisis in a social and environmental sense. The term "sustainable development" thus became the buzzword for alternative development strategies that could be "envisioned as continuing far into the future" [3]. There are several definitions of sustainability, but some are more inclusive than others. The official definition adopted by the United Nations (UN) came from the Brundtland report which defined sustainable as "development that meets the needs of the present generation without compromising the ability of future generations to meet their own needs" [5].

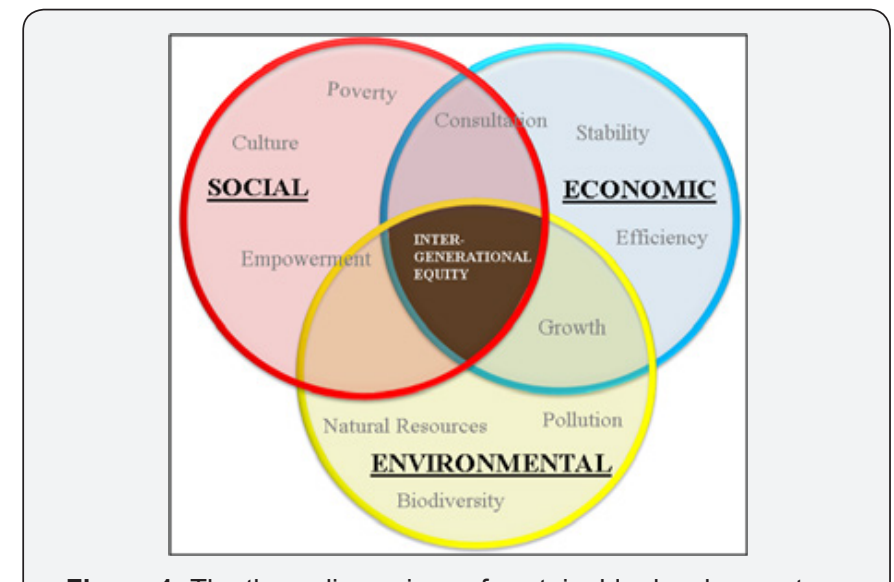

Figure 1: The three dimensions of sustainable development.

There are commonly three associated dimensions of sustainable development as identified by (Figure 1. The dimensions address economic, social and environmental aspects [6]. The social dimension has also been called 'equity' making the trio known as the Three E's. Within this text, we will briefly describe the economic and environmental dimensions as it is said that the economic dimension tends to overshadow the equity and environmental dimensions [3]. Economic sustainability deals with capital which means it is commonly measured by money. The four types of capital are: manufacturing, natural, social and human capital. Manufacturing capital is traditionally defined as assets used to make goods and services like tools and machines. Natural capital deals with resources such as timber, water, fossil fuels, biodiversity, and ecological services. Social capital references human wellbeing at an organizational level. Ideal examples include neighborhood associations, cooperatives and civic groups. The fourth type of capital - Human capital - is similar to social capital, but differs in that it deals with human welfare at an individual level. According to Ekins [7], this is where a person's health, education, job skills and motivations are measured. Taken into an African context, these dimensions 
are bound to reveal contradictory results because of the extreme variedness of not only the people, but also the environment (Figure 1).

There are two measures of environmental sustainability weak and strong. Weak sustainability is evident when natural resources can be substituted whereas in strong sustainability, there is no resource substitution [7]. Weak sustainability infers that the depletion of one form of capital can be offset by the surplus from another; conversely, strong sustainability suggests a complimentary relationship between the various forms of capital negating any possibilities of substitution [8]. When considering a common focus, sustainability encompasses the following areas:

\section{a. Ocean Ecosystems \\ b. Natural land covers systems \\ c. Climate change \\ d. Urbanization \\ e. Human settlement \\ f. Energy resources [9].}

The concept is also grounded by a few basic principles. The first principle is, do not go over the carrying capacity of natural resources for example, $\mathrm{CO}_{2}$ levels should not surpass natural carbon sequestration levels. The second principle focuses on increasing efficiency; in this vain, technology can be used as a substitute for a resource. The third principle states that, when using renewable resources, the extraction rate shall not exceed replenishment rate. Finally, non renewable resources should not be used at a rate greater than the resource's rate of creation [7]. Ecological indicators are the main tools in measuring sustainable development. The United Nations mandates, through Agenda 21, encouraged the creation of more indicators that can help countries progress towards sustainable development [10]. Consistent monitoring and evaluation of the progress is a necessity for two primary reasons: (1) to isolate emerging issues before they become costly problems; and (2), to assess plan implementation so they can be adjusted and improved [11].

\section{Ecological Indicators}

Sustainability measures are used in real world situations where the need is critical. In order to measure and monitor the health of the environment effectively, the indicators need to be aligned with certain criteria. The first criterion stipulates that an indicator should be simple to measure and easy to understand [12]. The second criteria state that the indicator must be sensitive to environmental stress. The third criterion is for the indicator to be predictable and not unambiguous. The remaining criteria are as such: the indicator should give an early warning of significant change in ecosystem; the indicator should be able to allow management to act by predicting change; the indicator must be comprehensive covering all the key section of an ecosystem; the indicator should have key responses to both natural and anthropogenic stresses on the ecosystem; and finally, the indicator should have a small range of variability [12]. Ideally, the indicators developed should satisfy all the criteria mentioned above; however, this is not always the case. Indicators have the power to demonstrate problems, motivate actions, and highlight the positive effects of sustainability policies - some of which are tied to state and national policies [3]. Sometimes, however, indicators have been developed for and used in regions for which it has no merit or relevance. The assumption within this text is that -errant measures (or outliers) are a sign of inadequacy within the group of indicators for a particular region, thus composite indicators can be extracted from the group to cover the inadequacies.

\section{The African Focus}

Africa, as the study area, was chosen for a variety of reasons. Africa is the second biggest and most populous continent in the world with about 1.1 billion people and the only continent to be represented in all four hemispheres. There are 53 countries and one disputed claim of sovereignty (Western Sahara). Many of these countries are under developed economically (poor) but extremely rich in mineral resources (which presents a contradiction) as 30 percent of the world's minerals are found in Africa. The landscapes are vast and heavily influence how people live. Africa is the hottest continent on the planet as 60 percent of land surface is dominated by desert. Only 10 percent is considered to be prime agricultural land [14]. Additionally, Africa is losing 4 million hectares of forest each year. This is double the rate when compared to the rest of the world. This is primarily due to logging, agriculture, building new houses, and road construction. Farmers are either forced to grow their crops on marginal lands that are not as productive, or quit and move to the cities because 65 percent of agriculture land and 31 percent of the pasture land is degraded. Africa is the second driest continent in the world after Australia. Water scarcity is a major problem and about 400 million people experience this due to natural conditions, desertification, land use change, and variable rainfall from $0 \mathrm{~mm}$ to $9500 \mathrm{~mm}$ [14]. Table 1 presents the major issues affecting the various countries in Africa which are grouped by the established regions. The distribution of the regions as well as the accompanying land cover is represented by the map in (Figure 2). The land cover clearly expresses the regional variability.

\section{Africa as Place}

Although Africa is urbanizing at an extremely fast rate $(2.32 \%$ between 2000 and 2005), most Africans still live in rural areas and 56.6 percent work in agriculture sector. At least 31 percent of Africa's population lives in urban areas and 72 percent live in slums. It is projected that by 2050 the population will reach between 1.9 and 2.5 billion people. By that time, over 60 percent of the population will live in urban areas. Only 2.7 percent live within $100 \mathrm{~km}$ of the coasts [15] (Table 1) (Figure 2). 


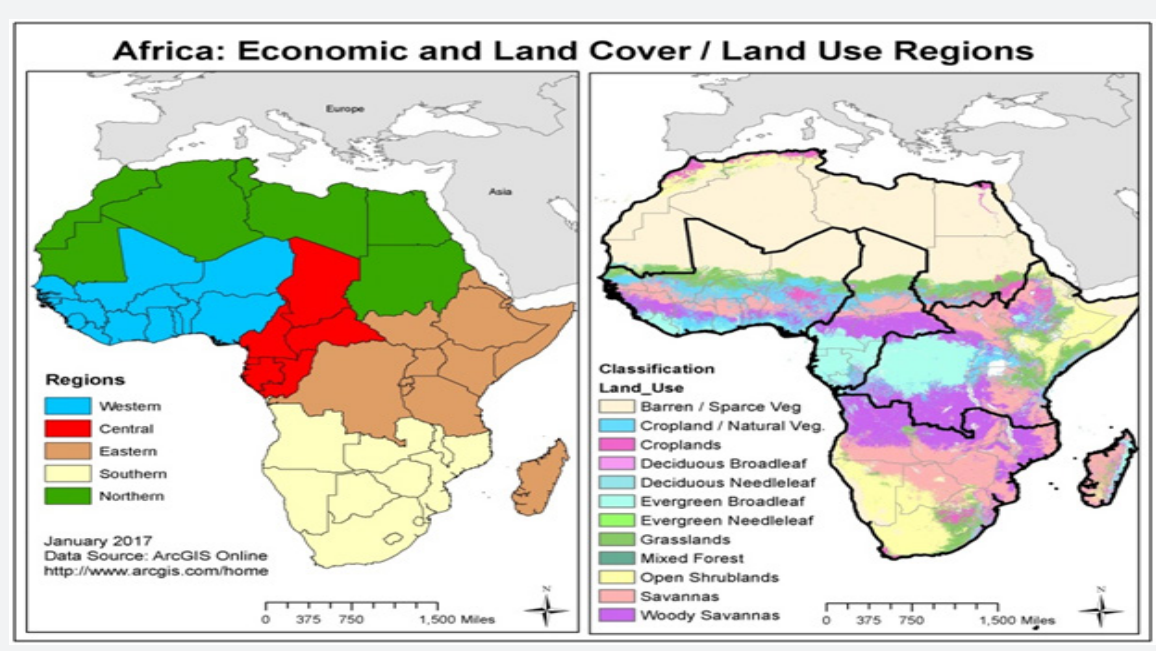

Figure 2: Depiction of the regions establish for analysis in this research. The land cover image was included as a referent to the variability of the Africa regions.

Table 1: Major issues affecting individual African countries broken down by region.

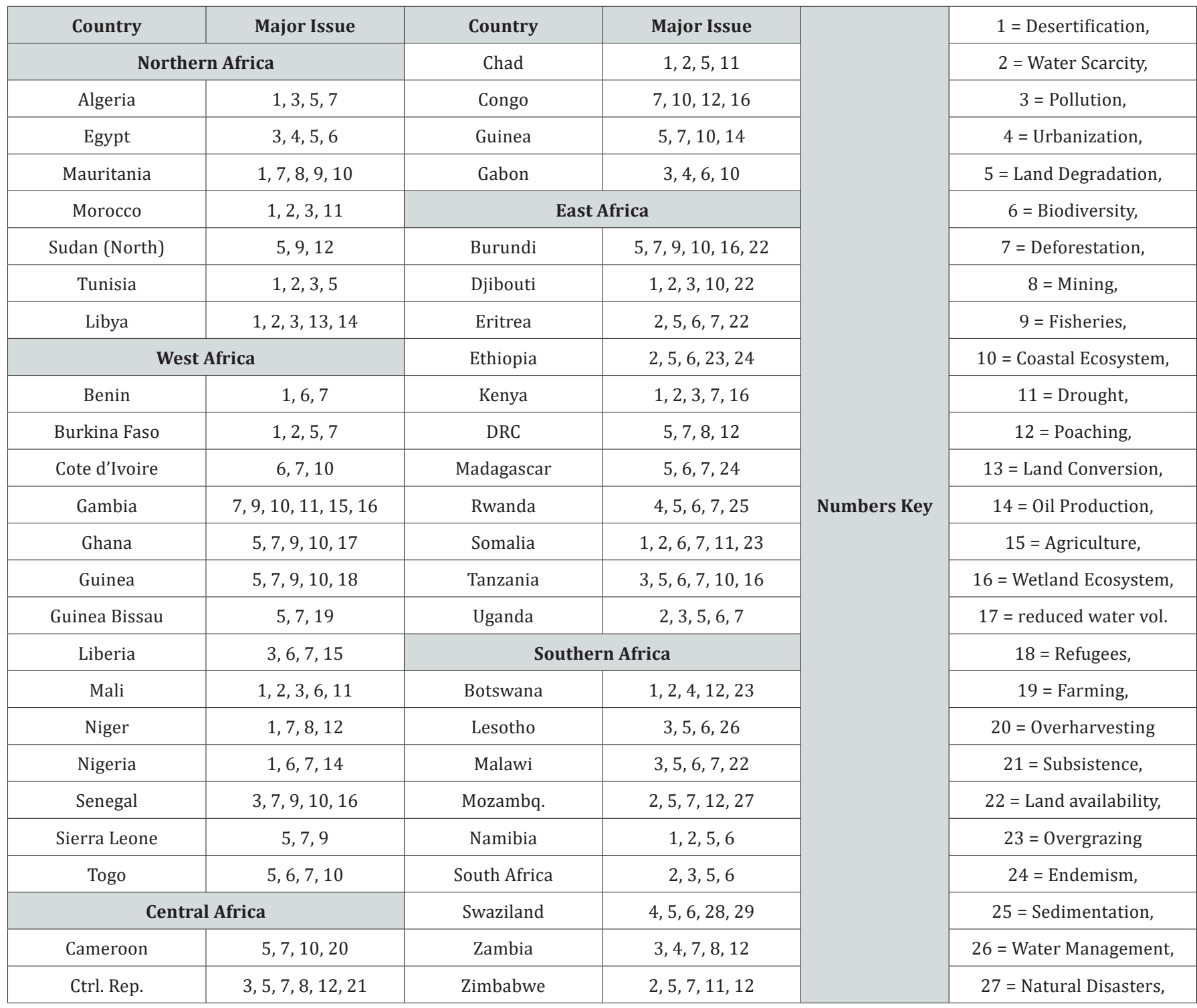


Africa is the poorest continent in world. Despite its reference as the birthplace of man, it has fallen behind the rest of world in every social and economic category. Most countries in Africa are last in basic human welfare. The AIDS epidemic is alarmingly high, average life expectancy is low and most governments lack the ability to feed their people. Yet, Africa is rich in mineral, natural, and energy resources [16]. Africa has amazing landscapes which are habitats for a multitude of large mammals. Unfortunately, in an effort to modernize, the one category that Africa has in abundance (the environment) is being degraded at the fastest rate in the world. Africans are now being challenged by the world [17] to find a way to develop sustainable without permanently damaging their best asset [18].

There are several theories as to why Africa is so poor. The first has to do with climate and weather. Africa is the second driest continent in the world and it is also the hottest - about 60 percent of the land is desert. Only ten percent of land is suitable for growing crops [14]. Most of Africa suffers from long dry seasons and heavy rain seasons which, again, is not suitable for many crops thus soil quality in generally is poor [18]. Second, the geography of Africa's coastline is straight this means that there are few natural inlets or natural areas to port along the coast making trade difficult. The third reason from a historical perspective is the Berlin Conference of 1884. This conference is noted for allowing the European countries to divide up Africa amongst themselves. They created countries without counsel from the native population resulting in the separation of once cohesive tribes. The outcome has manifested itself in today's post Colonial world. For example, Nigeria and many of the West African countries have two different cultural and physical regions. Muslims live in the northern savannahs while the Christians in the south live in tropical forests. The clash between these two cultures is just one example of the contributors to the slow growth of Africa - this is because conflict tends to cause destabilization when the disputes evolve into long protracted civil wars. The conflicts slow down the economy as trade and commerce are disrupted. Finally, colonization is implicated as it served to strip the continent of the easy access resources that were available. Knowing the history of the study area tends to help researchers understand why some regions within Africa are suffering from environmental deficiencies. It is important that they know the social, economic, institutional, and environmental characteristics of a region.

\section{Environmental Aspect}

The ecological footprint (EF) is an indicator of the environmental burdens that we put on the planet by representing the area of land needed to provide the raw materials, energy and food we consume as individuals or as a community [19]. In Africa, the EF has doubled since 1961 and is now over the regenerative capacity by 50 percent. Between 1961 and 2008, the EF increased by 238 percent. The bio capacity increased by 30 percent during this same time due to the increase in agriculture production. Unfortunately, with the increase in demand for resources, the bio capacity has decreased to 37 percent of its 1961 value. At least half of the countries in Africa are deficient in bio capacity. A combination of high rates of deforestation, a growing population, and continuous civil conflicts has impacted Africa's rich biodiversity negatively. Most of Africa's footprint is carbon based. Africa uses about 80 percent biomass as trees and charcoal is used to create energy. Deforestation rates are high because of the over reliance on biomass. Only 3 percent of electricity is used which is only 3 percent of the energy Africans use in general. The U.N. projects electricity usage to increase 6 fold with 80 percent of demand from growing urban areas [15] (Table 2).

Table 2: Indicators developed by the Committee of Sustainable Development (CSD) for Africa (UN Economic Commission for Africa 2012).

\begin{tabular}{|c|c|c|}
\hline Economic & Social & Environment \\
\hline $\begin{array}{c}\text {-GDP Composition } \\
\text { and Growth }\end{array}$ & -Poverty Level & -Land \\
\hline -GDP per Capita & -Income Distribution & -Energy \\
\hline $\begin{array}{c}\text {-Agricultural } \\
\text { Production }\end{array}$ & -Access to Sanitation & -Water \\
\hline -Exports & -Access to Water & -CO2 Emissions \\
\hline $\begin{array}{c}\text {-Savings and } \\
\text { Investment }\end{array}$ & -Population Growth & -Deforestation \\
\hline $\begin{array}{c}\text {-Foreign Direct } \\
\text { Investment }\end{array}$ & -Fertility & -Soil Degradation \\
\hline -ODA & -Child Mortality & Institutional \\
\hline -External Debt & -Maternal Mortality & $\begin{array}{c}\text {-Number of Parties to } \\
\text { following }\end{array}$ \\
\hline -Balance of Payments & -HIV/AIDS & Conventions \\
\hline -Terms of Trade & -Malaria and TB & -Basel \\
\hline $\begin{array}{c}\text {-Education } \\
\text { Expenditures }\end{array}$ & -Education & -CBD \\
\hline -Health Expenditures & -Illiteracy & -UNFCCC \\
\hline $\begin{array}{c}\text {-Roads } \\
\text {-ICT }\end{array}$ & & $\begin{array}{c}\text {-UNCCD } \\
\text {-Unemployment }\end{array}$ \\
\hline -Inflation Rate & & -POPs \\
\hline
\end{tabular}

With the intention of developing sustainably, African countries - under the guidance of the U.N began to develop indicators specific to Africa. The U.N. created a special committee called the U.N. Committee on Sustainable Development (UNCSD). After the U.N. conference on Environment and Development in 1992, the African countries began convening regional workshops on developing indicators for measuring their sustainable development. Despite these workshops, by 2001 little had been developed regarding Agenda 21with the World Summit on Sustainable Development (WSSD) pending 
for 2002. The African countries formed a New Partnership for African Development (NEPAD) this new comprehensive plan was formed to implement better strategies towards sustainable development. After the WSSD, the Economic Commission of Africa (ECA) commissioned a Sustainable Development Report on Africa (SDRA) for 2004 2005. This biannual report would assess the progress of African states in implementing the MDG and NEPAD planned at the WSSD. Table 2 presents the actual indicators that were developed by the UNCSD for Africa. There were a total of some forty odd indicators developed. Out of the fifty four nations on the continent, only about ten were tested; thus, the indicators used only represent $20 \%$ of Africa [6].With this notion in mind, a plausible focus of research could pertain to answering questions about the effectiveness of the indicators on the other 80 percent. The lack of testing for the appropriateness of the indicators could possibly account for the presence of significant outliers that would form the basis for this research.

\section{Methodology}

The goal of this research is to construct new viable composite indicators for the various African regions that can measure their progress towards sustainability. This will be done via principal component analysis - a multivariate data analysis tool used for data reduction. This research seeks to reduce the number of environmental indicators from twenty plus (Table 3) specially chosen indicators to a smaller number that can handle the same task more efficiently. The principal component technique is preferred because the method is a little more precise and stable than your straight forward Factor Analysis in reducing variables into reliable dimensions (Table 3).

Table 3: chosen specifically for use in this research.

\begin{tabular}{|c|c|}
\hline \multicolumn{2}{|c|}{ List of indices } \\
\hline 1. Health & $\begin{array}{l}\text { 12. Human Wellbeing Index } \\
\text { (HWI) }\end{array}$ \\
\hline 2. Natural Resource Depletion & $\begin{array}{l}\text { 13. Gross Domestic Product } \\
\text { (GDP) }\end{array}$ \\
\hline 3. Land Degradation & 14. Ecological Footprint (EF) \\
\hline 4. Fertility & 15. $\mathrm{CO}_{2}$ Emissions \\
\hline 5. Life Expectancy & 16. Urbanization \\
\hline 6. Sustainable Society Index (SSI) & 17. Happy Planet (HPI) \\
\hline 7. Biodiversity & 18. Forest \\
\hline 8. Greenhouse Gases (GHG) & 19. Arable \\
\hline 9. Renewable Energy & $\begin{array}{l}\text { 20. Environment Performance } \\
\text { Index (EPI) }\end{array}$ \\
\hline $\begin{array}{l}\text { 10. Human Development Index } \\
\text { (HDI) }\end{array}$ & 21. World Risk Index (WRI) \\
\hline 11. Ecological Wellbeing & \\
\hline
\end{tabular}

The PCA concentrates on the shared variance between each of the variables and delves into their correlation structure identifying the hidden components. This tool allows for the retention of more variables without succumbing to correlation bias - also known as multicollinearity [20]. The PCA is optimal for dealing with the issues of multicollinearity as it transforms the set of correlated variables into a set of uncorrelated principal components [21]. A prime example of variables that could have contributed to the bias would be the Health and Sufficient Food indicators $(\mathrm{r}=0.895)$. The reduced orthogonal components - also known dimensions or synthetic variables - reflect the underlying similarities of the initial variables [22]. This is aided by a Varimax rotation which associates each variable to, at most, one component. The rotation maximizes the sum of the variances simplifying the interpretation of the results. The following is the general formula for computing the first component created in a PCA: $\mathrm{C}_{1}=\mathrm{b}_{11}\left(\mathrm{X}_{1}\right)+\mathrm{b}_{12}\left(\mathrm{X}_{2}\right)+\ldots \mathrm{b}_{1 \mathrm{P}}\left(\mathrm{X}_{\mathrm{P}}\right)$ where $\mathrm{C}_{1}$ equals the subject's score on component $1, \mathrm{~b} 1 \mathrm{p}$ equals the coefficient for the observed variable $\mathrm{p}$ as used in creating principal component 1 , and $\mathrm{X}_{\mathrm{p}}$ equals the subject's score on observed variable $p$ [23].

The data for this research has been compiled from various databases to include the Nation Master [26], the Sustainable Society Index, and the World Bank Africa Development Indicators. The Africa Development Indicators are also available in time series from 1960 to 2012. The data for this research is divided into five groups representing the five African regions as previously seen in (Figure 2) and then standardized. In this analysis, the $\mathrm{Z}$ scores are used to determine how far a value is from the mean. If a variable's $\mathrm{Z}$ score falls within the normal range, that variable would not be chosen for the PCA. The outliers would be chosen. Any variable that has a value over or under (negative) two is considered an outlier as they are too high or too low (Figure 3). However not all outlier values will be picked - only the values having a negative effect on people and the environment was chosen. The results are reported based on region. Additionally, the new composite variables with their subjectively derived names will be reported. As stated above, the PCA is a data reduction method; thus, the resulting components (or synthetic variables) represent the characteristics of the underlying variables and are subjectively named on that basis (Figure 3).

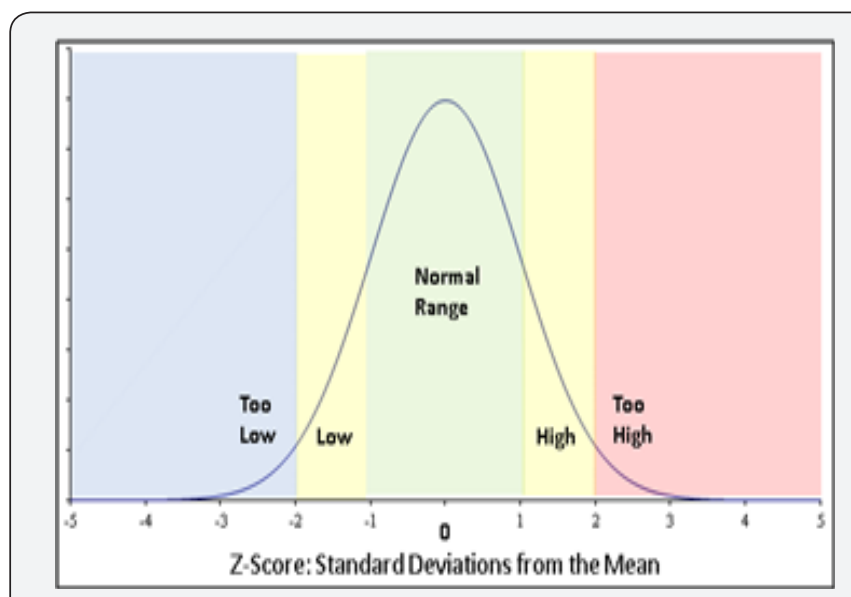

Figure 3: Sustainable Development Dimensions. Sustainable Development report by the United Nations Economic Commission for Africa, 2012. 
Results

\section{North Africa}

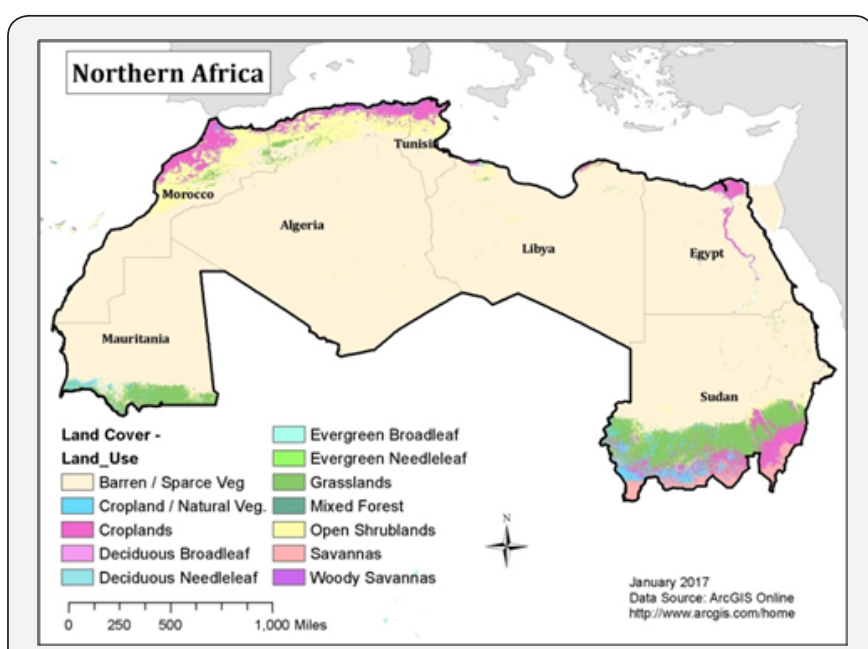

Figure 4: North African region countries and land cover.

North Africa is home to the largest desert on Earth the Sahara Desert. The desert spans the entire width of this region and covers the majority of the land area of the countries in this region (Figure 4). This results in the clustering of the populations in the associated countries along the semi arid Southern Mediterranean Sea coast. All indicator scores where standardized to make measurements equal. North Africa's HDI and HWI are above average when compared to the rest of Africa's HDI and HWI results, yet given the natural physical terrain the EWI is below average. Since this research concerns data reduction, the goal is to limit the number of indicators but still be able to accurately measure the specific phenomenon in question. The first round of elimination was done by way of $\mathrm{Z}$ scores. The indicators that had $\mathrm{Z}$ scores close to zero were eliminated. This ensures that the phenomenon the indicator was measuring was not a big issue compared to the others. For example, compared to the rest of the continent, the Air Quality and CO2 is not a big issue; as a result, these indicators were not included in the PCA data reduction analyst test. In contrast, the Environment Wellbeing (EWI) was included because the North Africa has the worst environmental levels. Results for North Africa are presented in Table 4. The indicators with extreme scores that are antithetical to sustainability are included while the indicators with average scores are excluded. This preliminary round of data reduction was done for all five regions. A correlation matrix showed that the correlation between variables was week in general. This explains the low KMO test readings. Ideally, the closer to 1.0 the readings are the greater the effect the indicators have on each other. For the results, the total variance section shows the combined percentage of variance the extracted components explain. In the individual component sections - with the individual subjectively assigned names the values in parentheses indicate the amount of variance the individual components account for. Typically, the first component always account for the highest percentage.
The numbering of the components indicates how many were extracted in the PCA process (for our regions, three components were extracted from each test) and the high loading variables $(>5)$ under each component. The extracted components represent a new (or synthetic) variable / indicator. Based on the analysis, it can be concluded that the three components (or indices) extracted can explain a substantial proportion of the environmental problems of North Africa. Thus, the indicators have been reduced in this analysis from six to three (Table 4).

Table 4: North Africa PCA results.

\begin{tabular}{|c|c|c|}
\hline $\begin{array}{c}\text { Components (percent } \\
\text { variance) }\end{array}$ & Loading & Additional \\
\hline $\begin{array}{l}\text { 1: Human Land Index } \\
(34.1 \%)\end{array}$ & & \multirow{4}{*}{$\begin{array}{l}\text { Kaiser-Meyer-Olkin } \\
(\text { KMO })=0.533\end{array}$} \\
\hline Total Population & 0.944 & \\
\hline Arable & 0.936 & \\
\hline $\begin{array}{l}\text { 2: North African Unhappy } \\
\text { Planet Index (27.7\%) }\end{array}$ & & \\
\hline Ecological Footprint (EF) & 0.849 & \multirow{5}{*}{$\begin{array}{c}\text { Total Variance } \\
\text { Explained }=81.4 \%\end{array}$} \\
\hline Ecological Wellbeing (EW) & -0.770 & \\
\hline Urbanization & 0.689 & \\
\hline $\begin{array}{l}\text { 3: Urban Resource Depletion } \\
\text { Index (19.6\%) }\end{array}$ & & \\
\hline Natural Resource Depletion & 0.936 & \\
\hline
\end{tabular}

North Africa is believed to have a population density problem. The population is found in clusters along the coast. Most the inland landscape (terrain) is dry and harsh to live on. The first component illustrates this problem. The arable and population variables are highly correlated. Based on those two high loadings, we aptly named Component 1 the Human Land Index (again, the naming convention is a subjective procedure because it is based on the research's interpretation of the high loading high loading variable under the component).Component two can be called Unhappy Planet Index. Ecological Footprint (EF) and Urbanization have a strong correlation whereas EWI has a strong negative correlation to both. EF and Urbanization are detrimental to the North African environment. Component three can be called Urban Resource Depletion Index because this is where Urbanization most likely causes natural resource depletion of land in North Africa.

\section{East Africa}

The landscape in East Africa is as diverse as its human population. Contained within its boundaries are world wonders like the Congo, Lake Victoria, the Serengeti plains and Mt. Kilimanjaro. Unlike the northern lands, however, East Africa has vast regions of lawlessness and non functional governments which means infrastructure is almost nonexistent. The countries of this region include Eritrea and Somalia and recently created South Sudan. This region is infamously known for food shortages due to ongoing civil strife which commonly result in famine. The desert is expanding southward causing mass migration, and 
the region is geologically active as the rift valley in Ethiopia is gradually pulling apart (Figure 5) (Table 5).

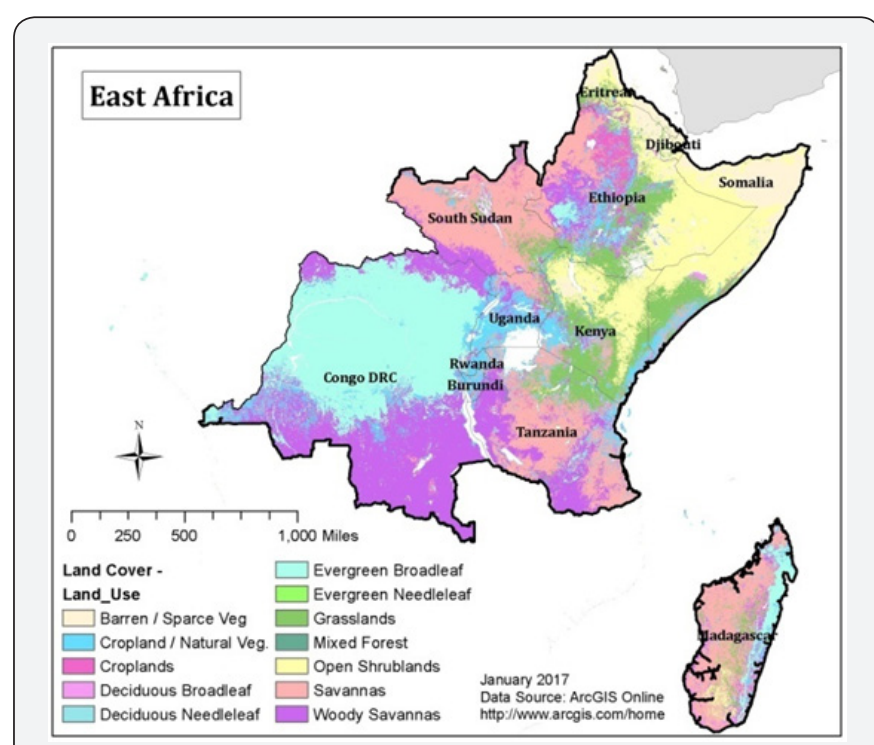

Figure 5: East African region countries and land cover.

Table 5: East Africa PCA results.

\begin{tabular}{|c|c|c|}
\hline $\begin{array}{l}\text { Components (percent } \\
\text { variance) }\end{array}$ & Loading & Additional \\
\hline 1: Culture Index (37.9\%) & & \multirow{5}{*}{$\begin{array}{c}\text { Kaiser-Meyer-Olkin } \\
(\text { KMO })=0.631\end{array}$} \\
\hline Life Expectancy & 0.890 & \\
\hline Health & 0.885 & \\
\hline $\begin{array}{l}\text { Sustainable Society Index } \\
\text { (SSI) }\end{array}$ & 0.802 & \\
\hline Happy Planet Index (HPI) & 0.749 & \\
\hline \multicolumn{2}{|l|}{$\begin{array}{l}\text { 2: Sustainable Index } \\
\qquad(23.2 \%)\end{array}$} & \multirow{6}{*}{$\begin{array}{c}\text { Total Variance } \\
\text { Explained }=74.5 \%\end{array}$} \\
\hline Urbanization & -0.890 & \\
\hline Renewable & 0.825 & \\
\hline $\begin{array}{c}\text { 3: Human Land } \\
\text { Degradation(13.4\%) }\end{array}$ & & \\
\hline Land Degradation & 0.761 & \\
\hline Total Population & 0.487 & \\
\hline
\end{tabular}

With respect to the analysis, the KMO Bartlett test was mediocre, but still registered as significant (Table 5). The amount of variance the combined components accounted for was 74.5 percent. The first component consists of four main variables the Happy Plant Index (HPI), Health, Life Expectancy and Sustainable Society Index [24].Based on its loading variables, Component 1 was named the East African Culture Index. The second component, on the other hand, consisted of Renewable and Urbanization. Urbanization has a strong negative correlation to Renewable the component was named the East Africa Sustainable Index. The third component variables of note were Land Degradation and Total Population. The others are not used due to low correlation to rest of variables, thus, this component was called East Africa Human Land Degradation.

\section{West Africa}

This part of Africa's environment varies from semi arid in Northern part to tropical in the Southern section (Figure 6). The area is rich in oil and minerals, and carries the largest population in Africa. Ironically, the Atlantic slave trade started in this region. The countries here were controlled or influenced by Europeans, but in contemporary times, this region has been plagued by seemingly perpetual civil conflicts that causes political instability and poor infrastructure. The arable land is used for cash crops for exports rather than for feeding the population (Figure 6).

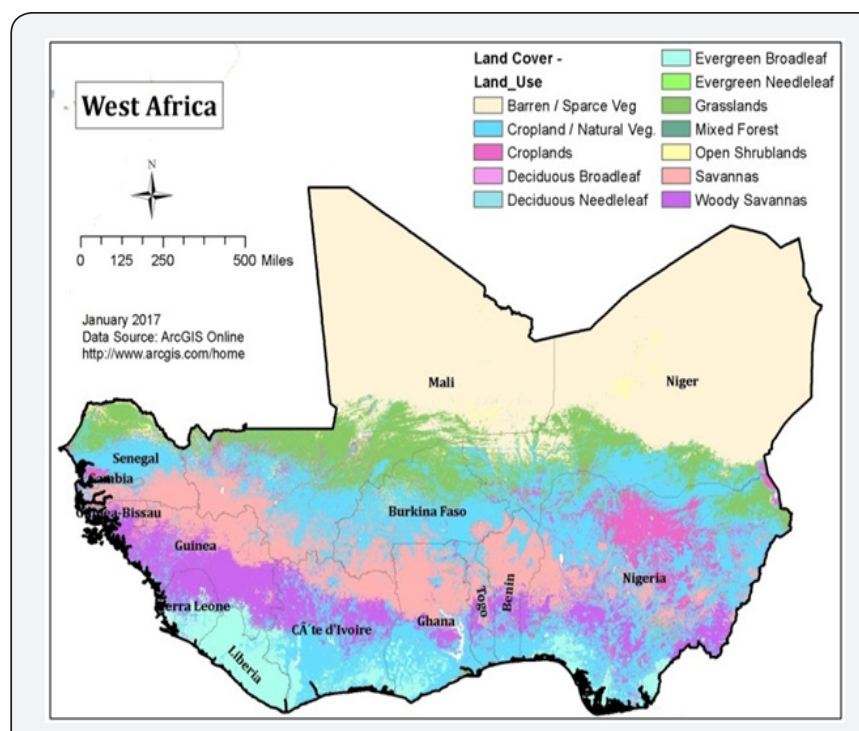

Figure 6: West African region countries and land cover.

From the start, there were six outlier variables. This test barely passes the KMO test as the correlation was low. It did, however, pass the significance test, and the total variance accounted for was over 76 percent (Table 6). Once again, three components were produced. After rotation, the first component consisted of the Arable and Total population variables (Table 6).

Table 6: West Africa PCA results.

\begin{tabular}{|c|c|c|}
\hline $\begin{array}{c}\text { Components (percent } \\
\text { variance) }\end{array}$ & Loading & Additional \\
\hline \multicolumn{2}{|l|}{$\begin{array}{l}\text { 1: Human Land Index } \\
(35.2 \%)\end{array}$} & \multirow{3}{*}{$\begin{array}{l}\text { Kaiser-Meyer-Olkin } \\
\quad(\text { KMO })=0.529\end{array}$} \\
\hline Arable & 0.939 & \\
\hline Total Population & 0.918 & \\
\hline \multicolumn{2}{|l|}{$\begin{array}{l}\text { 2: Environmental Disaster } \\
\text { Response Index }(23.8 \%)\end{array}$} & \multirow{5}{*}{$\begin{array}{c}\text { Total Variance } \\
\text { Explained }=76.1 \%\end{array}$} \\
\hline World Risk Index (WRI) & -0.840 & \\
\hline $\begin{array}{c}\text { Environmental Performance } \\
\text { Index } 2010\end{array}$ & 0.833 & \\
\hline \multicolumn{2}{|l|}{$\begin{array}{l}\text { 3: Homicide Rate Index } \\
\text { (17.2\%) }\end{array}$} & \\
\hline Homicide Rate & 0.942 & \\
\hline
\end{tabular}


In similar fashion as the North Africa component, this one too will be called The Human Land Index. Component 2 has two high loading variables. Although the correlation between the World Risk Index and the Environmental Performance Index is negative, the relationship is actually positive when referencing disaster preparedness. The World Risk Index (WRI) measures the potential risk of natural disaster and how prepared a country is to deal with this potential disaster. The risk of disaster is low which means that the environment has a much better chance of remaining healthy; thus, this component was labeled Environmental Disaster Response Index. Finally, the third component contained one high loading variable Homicide Rate. Since this is the best descriptor, there is no need to change the name.

\section{Central Africa}

This region is the smallest out of the five U.N. designated regions in Africa. The environment includes tropical forest in South which gradually changes to semi arid as you progress northward (Figure 7).

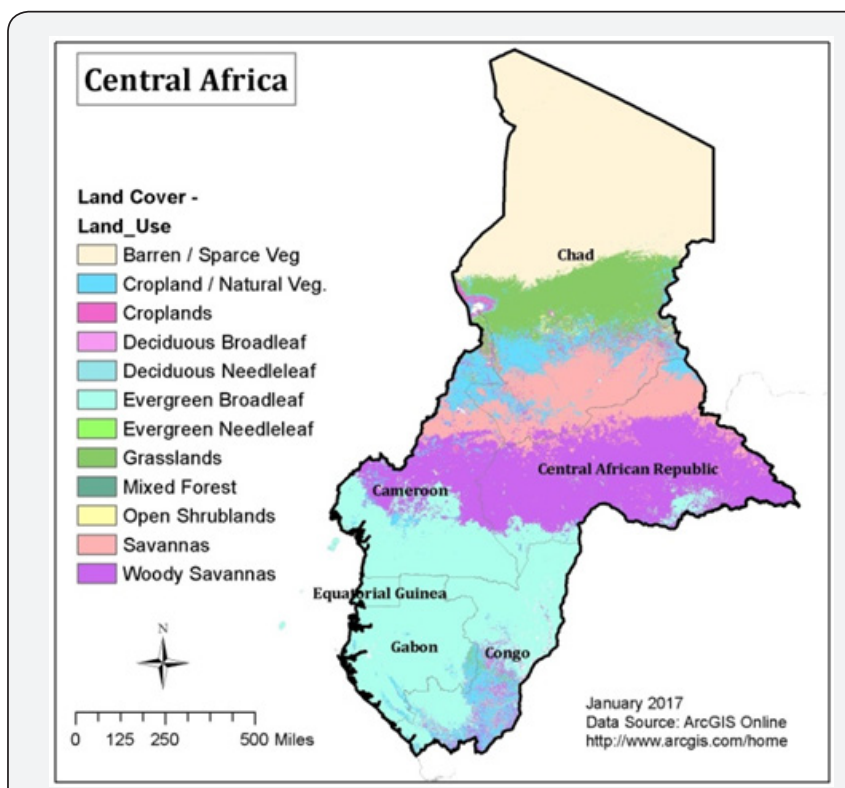

Figure 7: Central African region countries and land cover.

All the countries in this region are poor and it is said to be the birthplace of acquired immune efficiency syndrome (AIDS) in humans. Nine variables were found to be outliers. The region is prone to health, air quality and lose of natural resource issues. The variables past the KMO and Bartlett test and the three components extracted explain $77 \%$ of the variance. Component 1 reveals a multitude of issues with the quality of the atmosphere - both in urban and rural areas; therefore, an appropriate name for this component is the Total Atmospheric Quality Index. Component 2's major correlated variables were Health, Life Expectancy, Urbanization and HPI. It can be deducted that in Central Africa, the more urbanized areas have better health care systems. Unfortunately, there are not many urbanized areas in Central Africa, thus, a suitable name for this component was
Human Urbanized Health Index. Component 3's only viable variable was Natural Resource Depletion; thus, there was no need to attempt to interpret a name for the indicator (Table 7).

Table 7: Central Africa PCA results.

\begin{tabular}{|c|c|c|}
\hline \multicolumn{3}{|c|}{ Central Africa PCA results } \\
\hline Components & Loading & Additional \\
\hline $\begin{array}{c}\text { 1: Total Atmospheric } \\
\text { Quality Index (44.3\%) }\end{array}$ & & \multirow{5}{*}{$\begin{array}{l}\text { Kaiser-Meyer-Olkir } \\
\quad(\text { KMO })=0.679\end{array}$} \\
\hline Greenhouse Gases (GHG) & 0.941 & \\
\hline Air Quality & 0.833 & \\
\hline $\begin{array}{l}\text { Sustainable Society Index } \\
\text { (SSI) }\end{array}$ & 0.775 & \\
\hline $\mathrm{CO}_{2}$ Emissions & -0.542 & \\
\hline $\begin{array}{l}\text { 2: Human Urbanized } \\
\text { Health Index }(20.2 \%)\end{array}$ & & \multirow{7}{*}{$\begin{array}{c}\text { Total Variance } \\
\text { Explained }=77.1 \%\end{array}$} \\
\hline Live Expectancy & 0.901 & \\
\hline Health & 0.847 & \\
\hline Happy Planet Index (HPI) & 0.775 & \\
\hline Urbanization & -0.525 & \\
\hline $\begin{array}{l}\text { 3: Resource Depletion } \\
\text { Index }(12.6 \%)\end{array}$ & & \\
\hline $\begin{array}{l}\text { Natural Resource } \\
\text { Depletion }\end{array}$ & 0.928 & \\
\hline
\end{tabular}

\section{Southern Africa}

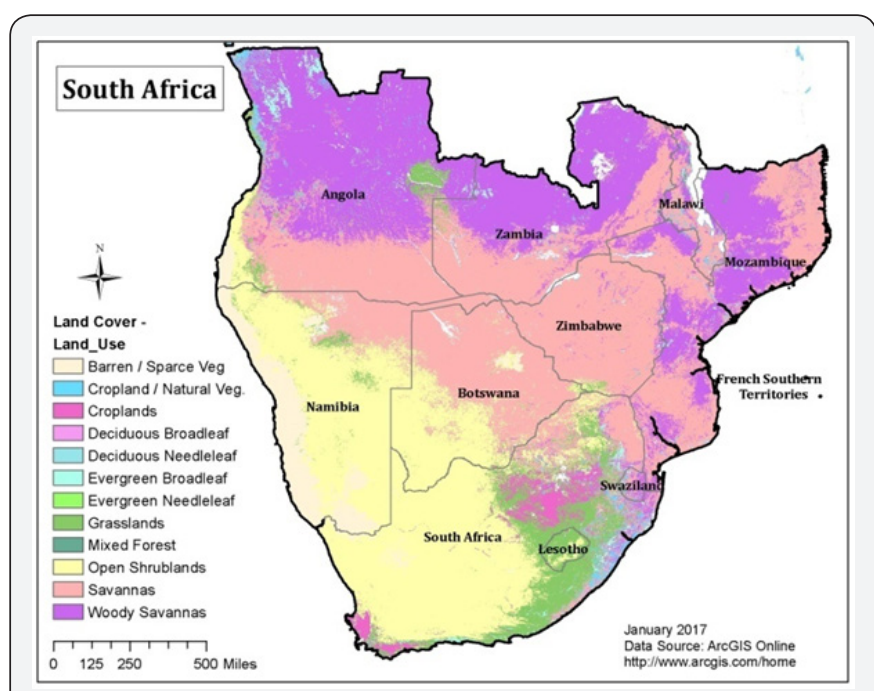

Figure 8: South African region countries and land cover.

This part of Africa is home to varied landscapes and climate zones. From the Coastal temperate climate in the South to semi arid plateau and mountains to very dry deserts in the Western section to tropical forests in Northern parts of this region (Figure 8). The climate in the Southern part attracted European settlers in the age of Exploration beginning in the 1600s. Additionally, the discovery of huge valuable mineral deposits such as gold and diamonds and vast fertile land further encouraged more European settlers to migrate. Unlike the rest of Africa, the settlers called this are home. It was not until recently that the 
true natives were allowed to re govern their own homeland. The Europeans brought their form of government to the region thus the region developed the same way European countries did. As a result, the area became Africa's most modern, industrialized and richest country. The entire region is politically stable, and the ecological problems now resemble that of European countries. The country of South Africa dominates the region. There were six variables that were found as outliers in the in this region (Table 8).

Table 8: Southern Africa PCA results.

\begin{tabular}{|c|c|c|}
\hline \multicolumn{3}{|c|}{ Southern Africa PCA results } \\
\hline Components & Loading & Additional \\
\hline 1: Good Air Index (41.8\%) & & \multirow{5}{*}{$\begin{array}{l}\text { Kaiser-Meyer-Olkin } \\
\quad(\mathrm{KMO})=0.664\end{array}$} \\
\hline Greenhouse Gases (GHG) & 0.893 & \\
\hline Air Quality & 0.838 & \\
\hline $\mathrm{CO}_{2}$ Emissions & -0.742 & \\
\hline World Risk Index (WRI) & 0.657 & \\
\hline $\begin{array}{l}\text { 2: Human Urbanized Health } \\
\text { Index }(19.6 \%)\end{array}$ & & \multirow{4}{*}{$\begin{array}{c}\text { Total Variance } \\
\text { Explained }=79.0 \%\end{array}$} \\
\hline Ecological Footprint (EF) & 0.921 & \\
\hline $\begin{array}{l}\text { 3: Urban Resource } \\
\text { Depletion Index (17.5\%) }\end{array}$ & & \\
\hline Arable & 0.965 & \\
\hline
\end{tabular}

The KMO was moderate but significant, and the extracted components explained 79 percent of the variance in the data. Component 1 suggest that WRI increases when both GHG and Air Quality worsen. Curiously, $\mathrm{CO}_{2}$ Emissions were negatively correlated. This could be indicative of a conscious effort to limit $\mathrm{CO}_{2}$ emissions. South Africa was able to lower their $\mathrm{CO}_{2}$ emissions before the 2002 U.N. conference on the environment; however, after the conference - the restrictions were lifted. The readings could also be related to the fact that some of the countries in the region are under populated. A suitable name for this component - based on the loading variables - was the Good Air index. Component 2 and 3 only have one suitable variable, thus the names were not changed.

\section{Conclusion}

Africa is a woefully underdeveloped continent in regards to human development compared to the rest of the world, but from an environmental standpoint, is arguably the richest. The goal of this research was to create a reduced set of viable composite indicators that can measure sustainability within the confines of the varied regions in Africa. First, it was necessary to divide the Africa up into five regions because each of the regions has varying physical features as well as cultures. Each of the regions also has their own issues. For example, North Africa's landscape varies from semi arid to arid therefore water and arable land availability was assumed to be the major issues for this region. However, after doing the PCA test it was revealed that - while water availability is a problem, it doesn't compare to arable land availability, population density, and urbanization problems. The population is found largely on the Mediterranean Coast where there is limited land to grow food and live on. The interior is barren and uninhabitable. Given the still growing population, the aforementioned issues could easily become catastrophic. As another example, we have East Africa. Here, the major problem is urbanization and land degradation, while health, life expectancy and SSI are high. While this is a good trend at present, the region's cities are growing thus causing more interaction between wildlife and people. There are many subcategories when referring to environmental problems; thus, it is not just about land degradation or wildlife loss.

Overall, the accurate application of the PCA for data reduction (or in this case indicator reduction) proved that the number of the indicators currently used in the African regions can be reduced into new composite indicators that would better reflect Africa's variability. The analysis reduced the regional indicators down to three per region. Additionally, the components extracted from each region accounted for between 75.4 to 81.4 percent of the variance in the data for the regions. It should also be noted that, out of the fifteen indicators extracted for the five regions, four were from the original list of indicators meaning that - eleven truly new composite indicators were derived. Another way of looking at this at the regional level is - where some twenty odd indicators could have been applied, only three would have sufficed. While this is encouraging - it is all academic. The indicators will ultimately need to be tested in practice to determine their feasibility. This testing is in progress via cluster analysis and the results will be reported at a future date.

It should be remembered that these African countries are relatively new in terms of governance. Historically, new countries have had to overcome internal conflict before prosperity. There are still vast tracks of untouched forests in Africa. African governments are increasingly becoming aware of the value of these undisturbed places and are putting forward plans to protect and limit human activity in these areas. Thus, the many problems of Africa are correctable and it would be wise to have adequate indicators to truly chart the changes for better or for worse.

\section{References}

1. Blackbourn David (2011) The Conquest of Nature: Water, Landscape, and the Making of Modern Germany. Random House, New York, pp. 512 .

2. Seidl Irmi, Clem Tisdell (1999) "Carrying capacity reconsidered: from Malthus' population theory to cultural carrying capacity." Ecological Economics 31(3): 395-408.

3. Wheeler Stephen M (2013) Planning for Sustainability: Creating Livable, Equitable and Ecological Communities. Routledge, London and New York, UK \& USA, pp. 288. 
4. Zoeteman Kees (2012) Sustainable Development Drivers: The Role of Leadership in Government, Business and NGO performance. Northampton: Edward Elgar Publishing, Inc pp. 360.

5. Tladi Dire (2007) Sustainable Development in International Law: An Analysis of Key Enviro-Economic Instruments. Pretoria University Law Press, Pretoria, South Africca, pp. 274.

6. UN Economic Commission for Africa (2012) Sustainable Development Report on Africa: Managing Land-Based Resources for Sustainable Development. UNCSD.

7. Ekins Paul (2011) Environmental Sustainability: From Environmental Valuation to the Sustainability Gap. Progress in Physical Geography 35 (5): 629-651.

8. Ang Frederic, Steven Van Passel (2012) “Beyond the Environmentalist's Paradox and the Debate on Weak versus Strong Sustainability." Bio Science 62 (3): 251-259.

9. Moldan Bedrich, Janouskova Svatava, Hak Tomas (2012) "How to understand and measure environmental sustainability: Indicators and targets." Ecological Indicators 17: 4-13.

10. Wilson J, Tyedmers P, Pelot R (2007)Contrasting and comparing sustainable development indicator metrics. Ecological Indicators 299314.

11. Leitmann Josef (1999) Sustaining Cities: Environmental Planning and Management in Urban Design. McGraw-Hill, Washington DC, USA.

12. Dale Virginia H, Suzanne C Beyeler (2001) Challenges in the Development and use of Ecological Indicators. Ecological Indicators 1(1): 3-10.

13. National Research Council (2005) Assessing and Managing the Ecological Impact of Paved Roads. National Academies Press, Washington DC, USA.

14. UNEP (2008) Africa: Atlas of Our Changing Environment. Nairobi, United National Environmental Program, Kenya.

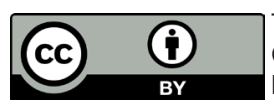

This work is licensed under Creative Commons Attribution 4.0 Licens

DOI: 10.19080/IJESNR.2017.01.555572
15.WWF (2012) Africa Ecological Footprint Report: Green Infrastructure for Africa's Ecological Security. Ecological Report, Gland: World Wide Fund for Nature \& African Development Bank.

16. Maathai, Wangari (2009) The Challenge for Africa. New York: Pantheon Books. Newyork, USA.

17. UN WRR (2012) World Risk Report. Alliance Development Works, United Nations University.

18. Moss Todd J (2007) African Development: Making Sense of the Issues and Actors. Boulder: Lynne Rienner Publishers, Inc ( $2^{\text {nd }}$ edn), pp. 290.

19. Dawkins E, A Paul, J Barrett, J Minx, K Scott (2008) Wales Ecological Footprint - Scenarios to 2020. Welsh Assembly Government, Stockholm: Stockholm Environment Institute.

20. Jolliffe IT (2002) Principal Component Analysis ( $2^{\text {nd }}$ edn), SpringerVerlag, New York, USA.

21. Liu RX, J Kuang Q, Gong, XL Hou (2003) Principal Component Regression Analysis with SPSS. Computer Methods and Programs in Biomedicine 71: 141-147.

22. O Brian DJ, JW Lloyd, JB Kaneene (1995) “A Principal Components Analysis of Factors Critical to Participation in Veterinary Lifelong Education Programs." Journal of Veterinary Medical Education 20 (3): 124-133.

23. Hatcher Larry (1994) A Step-by-Step Approach to Using SAS for Factor Analysis and Structural Equation Modeling. Cary, NC: SAS Institute Inc ( $2^{\text {nd }}$ edn) $)$ pp. 401.

24. Nation Master (2012) Country Profiles.

25. Happy Planet Index (2012) A global index of sustainable well -being.

26. SSI (2012) Sustainable Society Foundation.

\section{Your next submission with Juniper Publishers will reach you the below assets}

- Quality Editorial service

- Swift Peer Review

- Reprints availability

- E-prints Service

- Manuscript Podcast for convenient understanding

- Global attainment for your research

- Manuscript accessibility in different formats

( Pdf, E-pub, Full Text, Audio)

- Unceasing customer service

Track the below URL for one-step submission

https://juniperpublishers.com/online-submission.php 
